\title{
Pengaruh Strategi Directed Reading Thinking Activity (DRTA) Berbantuan Media Flip Chart Terhadap Keterampilan Membaca Pemahaman
}

\author{
Putu Novika Adi Karakaita Putri ${ }^{1 *}$, Ni Wayan Arini ${ }^{2}$, Md. Sumantri ${ }^{3}$ \\ 1,2,3 Jurusan PGSD, FIP Universitas Pendidikan Ganesha Singaraja, Indonesia
}

\author{
A R T I C L E I N F 0 \\ Article history: \\ Received 10 February \\ 2019 \\ Received in revised form \\ 09 March 2019 \\ Accepted 15 April 2019 \\ Available online 25 May \\ 2019 \\ Kata Kunci: \\ keterampilan membaca \\ pemahaman, DRTA, flip \\ chart. \\ Keywords: \\ reading comprehension, \\ DRTA, flip chart
}

\begin{abstract}
A B S T R A K
Penelitian ini bertujuan untuk mengetahui pengaruh yang signifikan keterampilan membaca pemahaman antara kelompok siswa yang dibelajarkan dengan menggunakan strategi pembelajaran Directed Reading Thinking Activity (DRTA) berbantuan media flip chart dan kelompok siswa yang tidak dibelajarkan dengan menggunakan strategi pembelajaran Directed Reading Thinking Activity (DRTA) berbantuan media flip chart pada siswa kelas V di Gugus IV Kecamatan Tejakula Tahun Pelajaran 2017/2018. Penelitian ini adalah penelitian semu (quasi experiment), dengan desain penelitian non-equivalent post-test only control group design. Sampel penelitian berjumlah 41 siswa, yang terdiri dari 21 siswa kelas V SD N 3 Bondalem sebagai kelompok eksperimen dan 20 siswa kelas V SD N 4 Bondalem sebagai sebagai kelompok kontrol. Pemilihan sampel menggunakan teknik random sampling. Data keterampilan membaca pemahaman dikumpulkan dengan instrumen berbentuk tes pilihan ganda. Analisis data menggunakan analisis statistik deskriptif dan analisis statistik inferensial (uji-t). Hasil penelitian menunjukkan bahwa $t_{\text {hitung }}>t_{\text {tabel }}\left(t_{\text {hitung }}=16,559>\right.$ $t_{\text {tabel }}=2,042$ ). Berdasarkan hasil penelitian dapat disimpulkan bahwa
\end{abstract} terdapat perbedaan yang signifikan keterampilan membaca pemahaman siswa yang dibelajarkan dengan menggunakan strategi pembelajaran Directed Reading Thinking Activity (DRTA) berbantuan media flip chart dan siswa yang tidak dibelajarkan dengan menggunakan strategi pembelajaran Directed Reading Thinking Activity (DRTA) berbantuan media flip chart pada kelas V di SD Gugus IV Kecamatan Tejakula Tahun Pelajaran 2017/2018.

\section{A B S T R A C T}

This study aimed to determine the significant effect of reading comprehension skills between groups of students who are taught by using learning strategies of Directed Reading Thinking Activity (DRTA) with flip chart and group of students who are not learned by using learning strategy of Directed Reading Thinking Activity (DRTA) with flip charts on on fifth graders of Tejakula district primary schools cluster IV academic year 2017/2018. This research is quasi experiment, with nonequivalent research design post-test only control group design. The sample of the study was 41 students, consisting of 21 students of grade V SD N 3 Bondalem as experimental group and 20 students of grade V SD N 4 Bondalem as the control group. Sample selection using random sampling technique. Skill reading comprehension data is collected with multiple choice test instruments. Data analysis used descriptive statistical analysis and inferential statistical analysis (t-test). The results showed that thitung $>$ ttable (tcv $=16,559>$ tobs $=2,042)$. Based on the results of this study, it can be concluded that there is a significant difference of reading comprehension skills of students who are taught by using learning strategy of Directed Reading Thinking Activity (DRTA) with flip chart and students who are not learned by using learning strategy of Directed Reading Thinking Activity (DRTA) chart on on fifth graders of Tejakula district primary schools cluster IV academic year 2017/2018.

Copyright (C) Universitas Pendidikan Ganesha. All rights reserved. 


\section{Pendahuluan}

Bahasa merupakan salah satu alat komunikasi yang digunakan oleh manusia.Sebelum adanya bahasa tulis, manusia berkomunikasi menggunakan bahasa lisan. Seiring dengan kemajuan zaman dan teknologi dewasa ini, membuat manusia merasa ada keterbatasan dalam berkomunikasi menggunakan bahasa lisan. Selain itu informasi-informasi yang didapat melalui bahasa lisan juga akan cepat sirna setelah komunikasi lisan selesai. Maka dari itu, manusia mulai menciptakan simbol-simbol tulis untuk menuliskan bahasa lisannya dan dikenal dengan bahasa tulis.

Bahasa tulis ini terdapat dua kemampuan yang terlibat, yaitu menulis dan membaca. "Membaca merupakan kegiatan memahami bahasa tulis". (Ketut Dibia, dkk 2007:103). Artinya, membaca merupakan suatu kegiatan yang dilakukan secara intensif dengan memperhatikan isi tulisan, struktur kalimat, atau kosakata yang digunakan dalam tulisan tersebut, sehingga dapat mengetahui makna yang berkembang dalam sebuah teks bacaan.

Membaca merupakan salah satu aspek keterampilan berbahasa.Empat aspek keterampilan berbahasa yakni (1) keterampilan menyimak, (2) keterampilan berbicara, (3) keterampilan membaca, (4) keterampilan menulis. Keempat aspek tersebut saling berhubungan dan saling mempengaruhi satu sama lain dalam pengajaran bahasa.

Salah satu bidang aktivitas dan materi pengajaran bahasa Indonesia di Sekolah Dasar yang memegang peranan penting ialah pembelajaran membaca. Ilmu yang diperoleh siswa tidak hanya didapat dari proses belajar mengajar di sekolah, tetapi juga dalam kegiatan membaca dalam kehidupan seharihari. Oleh karena itu, kemampuan membaca dan memahami bacaan bagian penting dalam penguasaan dan peningkatan ilmu pengetahuan siswa."Membaca adalah suatu proses yang dilakukan serta dipergunakan oleh pembaca untuk memperoleh pesan yang hendak disampaikan oleh penulis melalui media kata-kata/bahasa tulis" (Tarigan, 1986:7).

Tujuan akhir membaca adalah memahami isi bacaan. Pemahaman tersebut merupakan salah satu kegiatan yang penting dalam rangka memperoleh ilmu pengetahuan dan informasi. Kemampuan membaca pemahaman merupakan bekal dan kunci keberhasilan siswa dalam menjalani proses pendidikan. Sebagaimana yang dijelaskan Burn, dkk (dalam Rahim, 2008:1) kemampuan membaca adalah sesuatu yang vital dalam suatu masyarakat terpelajar. Namun, anak-anak yang tidak memahami pentingnya belajar membaca tidak akan termotivasi untuk belajar. Belajar membaca merupakan usaha yang terus menerus. Anak-anak yang melihat tingginya nilai membaca dalam kegiatan pribadinya akan lebih giat belajar dibandingkan dengan anak-anak yang tidak menemukan keuntungan dari kegiatan membaca. Selain itu dengan seringnya membaca dan beragam tema bacaan yang dibaca siswa, maka siswa makin terbuka dalam memperoleh tambahan sejumlah kata-kata dan memperkaya wawasan pengetahuan dan pengalamannya.

Namun, kenyataan yang terjadi di lapangan khususnya di SD gugus IV Kecamatan Tejakula keterampilan membaca siswa kelas V tahun pelajaran 2017/2018 masih di bawah KKM. Hal ini diketahui setelah dilakukan wawancara serta observasi kelas V di gugus IV kecamatan Tejakula. Dalam wawancara yang telah dilakukan diperoleh informasi bahwa ada berbagai penyebab rendahnya keterampilan membaca pemahaman siswa dalam kegiatan pembelajaran. Guru menyatakan lebih sering menggunakan metode ceramah karena materi yang disampaikan cukup banyak dan guru beranggapan siswa akan lebih cepat mengerti dengan apa yang guru sampaikan, guru juga menyatakan dalam pembelajaran guru tidak menggunakan media, karena menggunakan media disetiap pembelajaran akan membutuhkan banyak waktu untuk pembuatannya dan memerlukan biaya yang cukup mahal.

Selain wawancara, dilakukan pula observasi pada saat proses pembelajaran di dalam kelas yang dilakukan pada tanggal 7 Desember 2017, ditemukan beberapa permasalahan dalam proses pembelajaran diantaranya: (1) dalam pembelajaran guru lebih sering menggunakan metode ceramah, (2) kurang menggunakan media yang relevan dan menarik semangat belajar siswa, sehingga perhatian siswa dalam pelajaran Bahasa Indonesia masih kurang aktif (3) bahan bacaan atau buku-buku yang digunakan dalam pembelajaran kurang menarik dan lengkap, sehingga kebiasaan membaca masih belum tampak.

Hal ini juga diperkuat dengan catatan dokumen yang diperoleh berupa nilai rata-rata keterampilan membaca pemahaman Bahasa Indonesia semester I kelas V di Gugus IV Kecamatan Tejakula Tahun Pelajaran 2017/2018 yang disajikan dalam Tabel 1. sebagai berikut. 
Tabel 1. Data Nilai Rata-rata Keterampilan Membaca Pemahaman Mata Pelajaran Bahasa Indonesia Siswa Kelas V Semester I di Gugus IV Kecamatan Tejakula Tahun Pelajaran 2017/2018

\begin{tabular}{clccccccc}
\hline No. & Nama Sekolah & KKM & $\begin{array}{c}\text { Jumlah } \\
\text { Siswa }\end{array}$ & & $\begin{array}{c}\text { Siswa yang } \\
\text { Mencapai KKM }\end{array}$ & $\begin{array}{c}\text { Siswa yang } \\
\text { Belum Mencapai } \\
\text { KKM }\end{array}$ & $\begin{array}{c}\text { Rata-rata } \\
\text { Keterampilan } \\
\text { Membaca } \\
\text { Pemahaman }\end{array}$ \\
\hline 1 & & & & Siswa & $\%$ & Siswa & $\%$ & 60,41 \\
2 & SD N 2 Bondalem & 66 & 29 & 11 & 37,93 & 18 & 62,07 & 51,00 \\
3 & SD N 3 Bondalem & 68 & 20 & 3 & 15,00 & 17 & 85,00 & 57,80 \\
4 & SD N 5 Bondalem & 68 & 21 & 9 & 42,85 & 12 & 57,15 & 64,10 \\
5 & SD N 6 Bondalem & 68 & 20 & 8 & 40,00 & 12 & 60,00 & 63,44 \\
6 & SD N 7 Bondalem & 65 & 34 & 13 & 38,23 & 21 & 61,77 & 63,85 \\
7 & SD N 8 Bondalem & 65 & 17 & 7 & 33,33 & 14 & 66,67 & 64,65 \\
& Jumlah & 67 & 162 & 58 & 35 & 104 & 65 & 60,75 \\
\hline
\end{tabular}

Berdasarkan data nilai rata-rata keterampilan membaca pemahaman mata pelajaran Bahasa Indonesia siswa kelas $\mathrm{V}$ pada Tabel 1 di atas dapat disimpulkan bahwa rentangan nilai keterampilan membaca pemahaman semester I tahun pelajaran 2017/2018 adalah 51,00 - 64,65 tersebut tergolong sedang menurut "kriteria penilaian acuan patokan PAP skala lima" (Agung, 2014:118). Berdasarkan hasil tersebut, perlunya guru untuk mengubah cara mengajar dengan menggunakan strategi serta menggunakan media untuk menunjang situasi pembelajaran Bahasa Indonesia agar lebih menarik.

Penggunaan strategi pembelajaran merupakan upaya yang dapat dilakukan oleh guru untuk memberikan materi agar lebih mudah diterima oleh siswa, salah satu alternatif yang dapat dilakukan untuk meningkatkan membaca pemahaman siswa kelas V semester II SD di gugus IV Kecamatan Tejakula, maka diperlukan sebuah strategi pengajaran yang sesuai agar membaca pemahaman siswa dapat optimal. Salah satu strategi yang dianggap tepat adalah strategi Directed Reading Thinking Activity (DRTA).

Strategi Directed Reading Thinking Activity yang selanjutnya dalam tulisan ini disingkat (DRTA). Strategi ini pertama kali dikonsep dan disempurnakan oleh Stauffer (1969) adalah kegiatan yang efektif yang dapat membantu siswa untuk memahami teks. Menurut Stauffer, membaca itu seperti proses kejiwaan. Membaca memerlukan simbol-simbol (kata-kata) yang merupakan ringkasan dari ide-ide atau konsep-konsep yang dihasilkan oleh penulis. Jadi, membaca menuntut pembaca menggunakan pengalaman dan pengetahuannya untuk merekonstruksi ide-ide atau konsepkonsep yang dihasilkan oleh penulis. Proses dari rekonstruksi ini akan selalu berubah selama proses membaca (Anggreni ,2013).

Strategi Directed Reading Thinking Activity (DRTA) dapat digunakan oleh guru dalam mengoptimalkan membaca pemahaman siswa.Selain meningkatkan membaca, strategi ini merangsang siswa untuk berpikir sebelum membaca, merangsang ingatan siswa sebelum membaca dan menguji pengetahuan siswa tentang suatu objek, serta melatih keberanian dalam berpendapat dengan prediksiprediksi mereka. Strategi Directed Reading Thinking Activity (DRTA) merupakan suatu strategi yang memfokuskan keterlibatan siswa dalam memprediksi dan membuktikan prediksinya ketika mereka membaca teks (Rahim, 2008).

Stauffer (dalam Hairuddin, dkk, 2007:3-24) menyatakan, strategi Directed Reading Thinking Activity (DRTA) dapat mendorong siswa mengambangkan kemampuan berpikir melalui keterampilan membaca. Strategi dirancang untuk meminta siswa memprediksi isi bacaan dan isi paragraf berdasarkan pengetahuan dan pengalaman yang telah dimiliki siswa, memikirkan prediksi saat membaca dan menguji/merevisi yang berhubungan dengan bacaan.

Strategi DRTA ini memfokuskan keterlibatan siswa terhadap teks bacaan, karena siswa memprediksi dan membuktikannya ketika mereka membaca. Menurut Khomariah (2013:5), strategi pembelajaran DRTA atau Directed Reading Thinking Activity merupakan strategi untuk mengembangkan kemampuan membaca secara komprehensif, membaca kritis, dan mengembangkan perolehan pengalaman siswa berdasarkan bentuk dan isi bacaan secara ekstensif. Awalnya siswa diajak untuk membuat prediksi tentang apa yang terjadi dalam suatu teks melalui media bergambar yang dapat mendorong anak-anak berfikir tentang pesan teks. Kemudian dalam membuat prediksi, prediksi masingmasing siswa akan berbedakarena siswa berpikir sesuai dengan jalan pikirannya siswa sendiri, dan guru harus menerima prediksi yang dikemukakan siswa (Fatih ,2019).

Strategi Directed Reading Thinking Activity (DRTA) menurut Stauffer (dalam Rahim 2008:47) merupakan suatu strategi yang memfokuskan keterlibatan siswa dalam memprediksi dan membuktikan prediksinya ketika mereka membaca teks. Selain itu keunggulan dari strategi DRTA dibandingkan dengan strategi membaca lainnya yaitu dengan adanya bantuan gambar. Rasa keingintahuan terhadap jawaban, 
akan meningkatkan motivasi untuk lebih cermat dalam membaca teks tersebut. Sehingga mereka dapat memahami bacaan dan menemukan kalimat utama dengan mudah (Lutfiana ,2017).

Strategi DRTA ini merupakan penyempurnaan dari strategi sebelumnya yaitu strategi Direct Reading Activity (DRA). Menurut Stauffer yang merupakan penggagas DRTA (dalam Abidin 2012:80) mengatakan bahwa DRA kurang memerhatikan keterlibatan siswa berpikir tentang bacaan. Dalam pembelajaran DRA proses keterlibatan hanya mengarah pada perintah guru, sedangkan untuk DRTA mampu memfokuskan keterlibatan siswa dalam memahami suatu teks bacaan, karena pada strategi ini siswa diharapkan mampu membuat prediksi dan membuktikannya pada saat mereka membaca (Fikri ,2013).

Dapat diartikan bahwa Directed Reading Thinking Activity (DRTA) salah satu upaya untuk mengoptimalkan pembelajaran membaca pemahaman sebagai salah satu bentuk pembelajaran membaca dan keterampilan berbahasa di sekolah dasar. Dalam kegiatan ini, siswa diajak untuk memprediksikan tentang apa yang ada dalam suatu teks sehingga mampu mendorong siswa untuk berpikir tentang pesan yang terkandung di dalam teks bacaan.

Untuk memaksimalkan penggunaan strategi Directed Reading Thinking Activity (DRTA), pembelajaran perlu mempergunakan media. Salah satu media yang dapat digunakan adalah Flip Chart. "Flip Chart dalam pengertian yang sederhana adalah lembaran-lembaran kertas yang menyerupai album atau kalender berukuran $28 \times 21 \mathrm{~cm}$ sebagai fliplook yang disusun dalam urutan yang diikat pada bagian atasnya" (Susilana dan Riyana, 2009:87).

Penggunaan flip chart merupakan salah satu cara guru dalam menghemat waktu terutama untuk menulis di papan tulis. Penyajian informasi ini dapat berupa gambar, huruf, diagram, dan angka-angka. Sajian pada flip chart harus disesuaikan dengan jumlah dan jarak maksimum siswa dalam melihat flip chart tersebut dan direncanakan tempat yang sesuai dimana dan bagaimana flip chart tersebut ditempatkan.

Susilana dan Riyana (2009:87) menyatakan, flip chart merupakan salah satu media cetakan yang sederhana dan cukup efektif. Sederhana dilihat dari proses pembuatannya yang relatif mudah dan efektif karena flip chart dijadikan sebagai media penyampai pesan pembelajaran secara terencana maupun secara langsung dan menjadikan percepatan ketercapaian tujuan dengan menghemat waktu bagi guru untuk menulis atau menggambar di papan tulis. Selain itu, penyajian yang menarik akan membuat siswa menjadi lebih antusias, bisa juga digunakan di dalam maupun di luar kelas, dan juga dapat meningkatkan aktivitas belajar siswa jika dikelola dengan benar.

Menurut Stauffer dalam Rahim (2007:47) bahwa strategi DRTA merupakan suatu strategi yang memfokuskan keterlibatan siswa dalam memprediksi dan membuktikan prediksinya ketika mereka membaca teks. Lebih lanjut Stauffer menjelaskan bahwa guru bisa memotivasi usaha dan konsentrasi siswa dengan melibatkan mereka secara intelektual serta mendorong mereka merumuskan pertanyaan dan hipotesis, memproses informasi, dan mengevaluasi solusi sementara. Sedangkan strategi KWL merupakan strategi membaca dengan langkah-langkah apa yang diketahui (K), apa yang ingin diketahui (W), dan yang telah dipelajari (L). Strategi KWL memberikan kepada siswa tujuan membaca dan memberikan suatu peran aktif siswa sebelum, saat, dan sesudah membaca (Subhanato ,2018).

Berdasarkan paparan di atas, penggunaan strategi Directed Reading Thinking Activity (DRTA) menggunakan media flip chart diperkirakan berpengaruh terhadap keterampilan membaca pemahaman dalam pelajaran Bahasa Indonesia siswa kelas V SD tahun ajaran 2017/2018 di Gugus IV Kecamatan Tejakula. Untuk membuktikannya, dilakukan penelitian dengan judul Pengaruh Strategi Pembelajaran Directed Reading Thinking Activity (DRTA) Berbantuan Media Flip Chart Terhadap Keterampilan Membaca Pemahaman Bahasa Indonesia Siswa Kelas V SD di Gugus IV Kecamatan Tejakula Tahun Pelajaran 2017/2018.

\section{Metode}

Penelitian ini dilaksanakan di SD Gugus IV Kecamatan Tejakula tahun pelajaran 2017/2018. Penelitian ini merupakan penelitian eksperimen dengan jenis penelitian eksperimen semu (quasi experiment). Desain penelitian kuasi eksperimen ini bertujuan untuk menguji pengaruh suatu model pembelajaran dengan cara menerapkan treatment pada kelas eksperimen dan membandingkan hasilnya dengan kelas kontrol. Rancangan penelitian ini menggunakan rancangan non-equivalen post-test only control group design dengan pola sebagai berikut. 


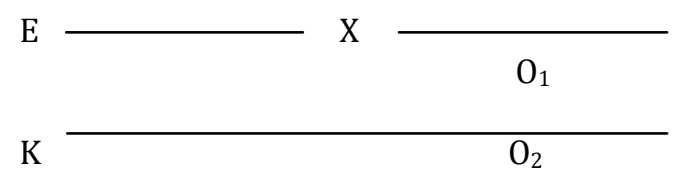

Keterangan:

(Sumber:dimodifikasi dari Sugiyono, 2012)

$\mathrm{E}=$ kelompok eksperimen

$\mathrm{K}$ = kelompok kontrol

$\mathrm{X}=$ Perlakuan berupa penerapan strategi pembelajaran Directed Reading Thinking Activity (DRTA) berbantuan media flip chart.

- = Tidak diberikan perlakuan strategi pembelajaran Directed Reading Thinking Activity (DRTA) berbantuan media flip chart.

$\mathrm{O}_{1}=$ Post-test terhadap kelompok eksperimen.

$\mathrm{O}_{2}=$ Post-test terhadap kelompok kontrol.

Populasi dalam penelitian ini adalah seluruh kelas V SD di Gugus IV Kecamatan Tejakula yang berjumlah 160 siswa. Sebelum menentukan kelas sampel terlebih dahulu dilakukan uji kesetaraan terhadap populasi penelitian. Berdasarkan hasil uji kesetaraan menggunakan ANAVA A, diperoleh seluruh populasi setara atau nilai keterampilan membaca siswa di SD Gugus IV Kecamatan Tejakula relatif sama. Selanjutnya, pengambilan sampel dilakukan dengan teknik simple random sampling, yaitu dengan sistem undian. Setelah dilakukannya pengundian terhadap sampel dalam populasi tersebut, yang menjadi sampel penelitian ini adalah siswa kelas V SD N 3 Bondalem dan SD N 4 Bondalem yang berjumlah 41 siswa. Kelas sampel yang telah didapatkan kemudian diundi lagi untuk menentukan kelompok eksperimen dan kelompok kontrol. Hasil pengundian diperoleh kelas V SD N 3 Bondalem sebagai kelompok eksperimen dan kelas V SD N 4 Bondalem sebagai kelompok kontrol. Kelompok eksperimen akan diberikan perlakuan dengan menggunakan strategi pembelajaran Directed Reading Thinking Activity (DRTA) berbantuan media flip chart sedangkan kelompok kontrol tidak diberikan perlakuan strategi pembelajaran Directed Reading Thinking Activity (DRTA) berbantuan media flip chart

Metode pengumpulan data dalam penelitian ini menggunakan metode tes untuk mengukur ranah kognitif siswa. Metode tes yang digunakan yaitu tes objektif. Tes objektif digunakan diakhir penelitian. Jumlah tes objektif sebanyak soal dengan mengikuti jenjang Taksonomi Bloom yang meliputi ranah kognitif aspek mengingat (C1), memahami (C2) mengaplikasikan (C3), menganalisis (C4), mengevaluasi (C5) dan menciptakan (C6). Teknik analisis data yang digunakan adalah teknik analisis deskriptif digunakan untuk mencari skor rata-rata/mean, median, modus, standar deviasi (SD), dan varians terhadap masing-masing kelompok. Mean, median, modus data sikap ilmiah siswa kemudian disajikan ke dalam grafik poligon. Penentuan tinggi rendahnya variabel-variabel penelitian dapat ditentukan dari skor ratarata tiap-tiap variabel dikonvensikan ke dalam PAP skala Lima. Teknik analisis statistik inferensial yang digunakan adalah uji-t independent dengan rumus polled varins untuk menguji hipotesis. Sebelum melakukan uji hipotesis terlebih dahulu dilakukan analisis uji prasyarat yang meliputi uji normalitas dan uji homogenitas.

\section{Hasil dan Pembahasan}

Data hasil penelitian ini yaitu data tentang keterampilan membaca pemahaman siswa yang diperoleh melalui post-tets. Deskripsi data keterampilan membaca pemahaman memaparkan nilai ratarata, median, modus, standar deviasi, dan varians. Deksripsi data keterampilan membaca pemahaman disajikan pada tabel 3 .

Tabel 2. Deskripsi Data Keterampilan Membaca Pemahaman

\begin{tabular}{ccc}
\hline Hasil Analisis & Kelompok Eksperimen & Kelompok Kontrol \\
\hline Mean & 35,95 & 22,60 \\
Median & 36,35 & 22,21 \\
Modus & 37,16 & 21,50 \\
Varians & 6,55 & 6,78 \\
Standar Deviasi & 2,56 & 2,38 \\
\hline
\end{tabular}

Mean, median, modus keterampilan membaca pemahaman selanjutnya disajikan kedalam kurva polygon. Tujuan dalam penyajian data ini yaitu untuk menafsirkan sabaran data keterampilan membaca 
pemahaman siswa. Hubungan antara mean (M), median (Me), dan modus (Mo) untuk menentukan kemiringan kurva polygon distribusi frekuensi.

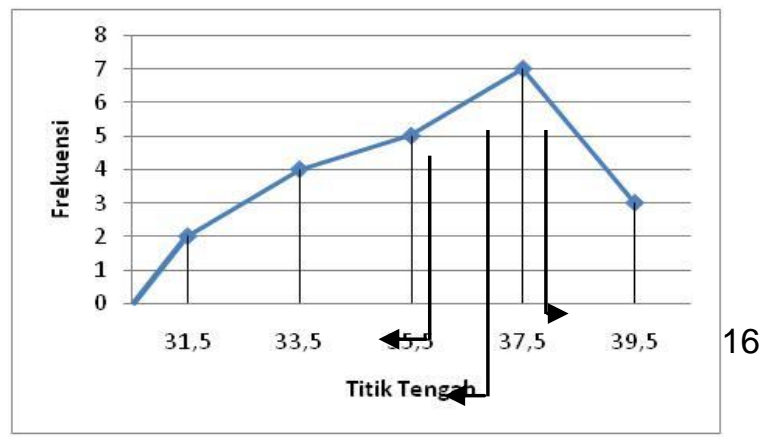

Gambar 1. Grafik Polygon Data Keterampilan membaca Pemahaman Kelompok Eksperimen

Skor mean (M), median (Me), modus (Mo) digambarkan pada grafik polygon tampak bahwa kurva sebaran data kelompok eksperimen menunjukkan juling negatif karena $M o>M d>M(37,16>36,35>35,95)$. Hal ini menunjukkan bahwa bagian besar skor keterampilan membaca pemahaman cenderung tinggi. Jika dikonvensikan ke dalam PAP skala. Lima keterampilan membaca pemahaman siswa kelompok eksperimen berada pada kategori sangat baik.

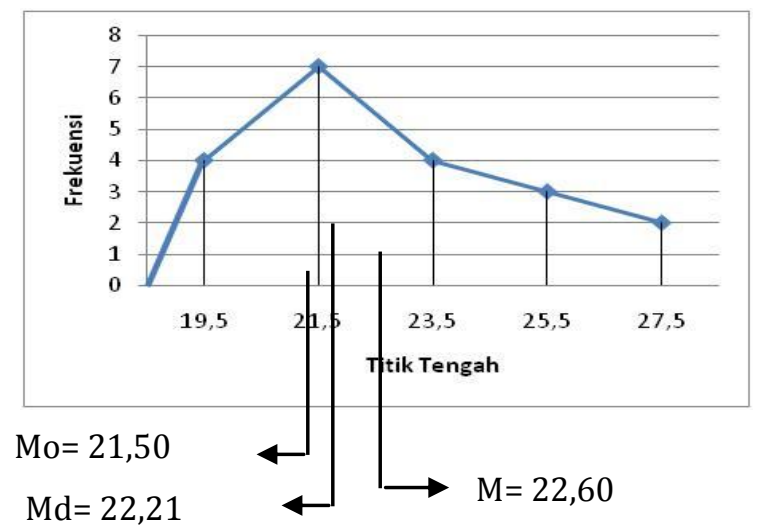

Gambar 2. Grafik Polygon Data Keterampilan Membaca Pemahaman Kelompok Kontrol

Skor mean (M), median (Md), modus (Mo) digambarkan pada grafik polygon tampak bahwa kurva sebaran data kelompok kontrol menunjukkan juling positif karena $\mathrm{Mo}<\mathrm{Md}<\mathrm{M}(21,50<22,21<22,60)$. Hal ini menunjukkan bahwa bagian besar skor keterampilan membaca pemahaman cenderung rendah. Jika dikonvensikan ke dalam PAP skala Lima keterampilan membaca pemahaman siswa kelompok kontrol berada pada kategori cukup.

Dari data tersebut menunjukkan bahwa kelompok ekspeimen yang dibelajarkan dengan menggunakan strategi pembelajaran Directed Reading Thinking Activity (DRTA) berbantuan media flip chart memiliki nilai rata-rata lebih tinggi dibandingkan kelompok kontrol yang dibelajarkan tidak menggunakan strategi pembelajaran Directed Reading Thinking Activity (DRTA) berbantuan media flip chart. Sebelum dilanjutkan pada pengujian hipotesis, terlebih dahulu dilakukan pengujian asumsi terhadap data yang diperoleh meliputi uji normalitas sebaran data dan uji homogenitas varians. Berdasarkan perhitungan data keterampilan membaca pemahaman dengan menggunakan rumus chikuadrat, diperoleh $\chi^{2}{ }_{\text {hit }}$ hasil post-test kelompok eksperimen adalah 0,960 dengan taraf signifikan 5\% $\mathrm{dan} \mathrm{db}=2$ diketahui $\chi^{2}{ }_{\text {tab }}$ 5,591. Hal ini menunjukkan $\chi_{\text {hit }}^{2}<\chi_{\text {tab }}^{2}$ maka data hasil keterampilan membaca pemahaman bahasa indonesia siswa di kelompok eksperimen berdistribusi normal

Hasil penghitungan data keterampilan membaca pemahaman dengan menggunakan rumus chikuadrat, diperoleh $\chi^{2}{ }_{\text {hit }}$ hasil post-test kelompok kontrol adalah 2,787 dan $\chi_{\text {tab }}^{2}$ dengan taraf signifikan $5 \%$ dan $\mathrm{db}=2$ adalah 5,591. Hal ini berarti $\chi^{2}{ }_{\text {hit }}<\chi^{2}{ }_{\text {tab }}$, sehingga data hasil post-test kelompok kontrol berdistribusi normal. 
Uji homogenitas varians antar kelompok eksperimen dan kelompok kontrol menggunakan uji Fisher . berdasarkan perhitungan dari uji homogenitas didapatkan $F_{\text {hitung }}=1,04$. Sedangkan nilai $F_{\text {tabel }}$ pada $\mathrm{db}_{\text {pembilang }}=20, \mathrm{db}_{\text {penyebut }}=19$, dan taraf signifikan $5 \%$ adalah 2,16 . Hal ini berarti $F_{\text {hitung }}=1,04<F_{\text {tabel }} 2,16$, sehingga keterampilan membaca pemahaman siswa pada kelompok eksperimen dan kelompok kontrol homogen.

Pengujian hipotesis menggunakan uji-t dengan rumus polled varians. Diketahui bahwa $\bar{X}_{1}=35,95$; $\bar{X}_{2}=22,60 ; S_{1}^{2}=6,55 ; S_{2}^{2}=6,78 ; \mathrm{n}_{1}=21 ;$ dan $\mathrm{n}_{2}=20$. Hasil perhitungan uji-t disajikan pada tabel 4 .

Tabel 3. Hasil Perhitungan Uji-t

\begin{tabular}{|c|c|c|c|c|c|c|}
\hline Data & Kelompok & $\mathrm{N}$ & $\bar{X}$ & $s^{2}$ & $t_{\text {hitung }}$ & $\mathrm{t}_{\text {tabel }}(\mathrm{t} . \mathrm{s} .5 \%)$ \\
\hline Keterampilan Membaca & Eksperimen & 21 & 35,95 & 6,55 & \multirow{2}{*}{16,559} & \multirow{2}{*}{2,042} \\
\hline Pemahaman & Kontrol & 20 & 22,60 & 6,78 & & \\
\hline
\end{tabular}

Berdasarkan Tabel 3, diketahui bahwa nilai $t_{\text {hitung }}$ lebih besar dari nilai $t_{\text {tabel }}$ yaitu $(16,559>2,042)$ sehingga $\mathrm{H}_{0}$ ditolak dan $\mathrm{H}_{\mathrm{I}}$ diterima. Hasil uji hipotesis tersebut, dapat diinterprestasi terdapat perbedaan yang signifikan keterampilan membaca pemahaman antara kelompok siswa yang dibelajarkan dengan menggunakan strategi pembelajaran Directed Reading Thinking Activity (DRTA) berbantuan media flip chart dibandingkan dengan kelompok siswa yang tidak dibelajarkan dengan menggunakan strategi pembelajaran Directed Reading Thinking Activity (DRTA) berbantuan media flip chart. Adanya perbedaan yang signifikan menunjukkan penggunaan strategi pembelajaran Directed Reading Thinking Activity (DRTA) berbantuan media flip chart berpengaruh positif terhadap keterampilan membaca pemahaman siswa kelas V SD di Gugus IV Kecamatan Tejakula tahun Pelajaran 2017/2018.

Hasil analisis data keterampilan membaca pemahaman siswa menunjukkan bahwa terdapat pengaruh yang signifikan pada mata pelajaran bahasa Indonesia antara kelompok siswa yang menggunakan strategi DRTA berbantuan media flip chart dan kelompok siswa yang tidak menggunakan strategi pembelajaran DRTA berbantuan media flip chart. Tinjauan ini didasarkan pada rata-rata skor keterampilan membaca pemahaman dan hasil uji-t.

Perbedaan hasil keterampilan membaca pemahaman antara kelompok siswa yang menggunakan strategi pembelajaran DRTA berbantuan media Flip Chart dan kelompok siswa yang tidak menggunakan strategi pembelajaran DRTA berbantuan media Flip Chart disebabkan oleh adanya perlakuan pada kegiatan pembelajaran di kelas. Kegiatan pembelajaran di dalam kelas eksperimen mengacu kepada tahap-tahap dari strategi pembelajaran DRTA berbantuan media Flip Chart. Perlakuan tersebut dilakukan dalam kegiatan pembelajaran dan berimbas pada proses penyampaian materi pembelajaran yang lebih baik.

Strategi pembelajaran DRTA berbantuan media Flip Chart juga berorientasi pada kemampuan berpikir kritis siswa dan merupakan suatu strategi yang digunakan dalam pengajaran membaca. Hal tersebut senada dengan pendapat Rahim (2008) yaitu strategi DRTA merupakan suatu strategi yang digunakan dalam pengajaran membaca melalui kemampuan berpikir kritis, bertindak dengan sadar, menyelidik, menggunakan pengalaman dan pengetahuannya, menilai fakta dan menarik kesimpulan berdasarkan fakta-fakta dan menghakimi atau membuat keputusan.

Selama proses pembelajaran berlangsung, guru hanya berperan sebagai fasilitator, moderator, dan motivator sehingga siswa dapat lebih aktif melakukan proses pembelajaran mulai dari membuat prediksi tentang isi bacaan berdasarkan judul atau gambar, membuat prediksi dalam batas waktu tertentu dan dilanjutkan dengan membacakan hasil prediksi masing-masing, kemudian proses membaca dengan sungguh-sungguh untuk membuktikan prediksi yang telah dibuat, mengoreksi prediksi yang telah dibuat, yaitu dengan mencocokan dengan hasil membaca, selanjutnya membuat ringkasan cerita dengan versi sendiri. Dengan menggunakan strategi pembelajaran DRTA, siswa lebih mudah memahami materi pembelajaran, dapat berinteraksi dan bekerjasama dengan orang lain, serta siswa dapat belajar dari pengalaman yang didapatnya saat proses pembelajaran berlangsung sehingga materi pembelajaran dapat diingat oleh siswa lebih lama dan proses pembelajaran menjadi lebih efektif. Temuan ini sesuai dengan hasil penelitian yang dilakukan oleh Eddy Trisna (2014) yang menyatakan bahwa dengan strategi pembelajaran DRTA siswa dapat lebih mudah memahami materi dan bekerjasama dalam kelompok, sehingga siswa mampu memahami materi yang disampaikan oleh guru secara efektif.

Penyampaian materi dalam pembelajaran menggunakan strategi pembelajaran DRTA berbantuan media flip chart disajikan dalam bentuk gambar oleh guru di depan kelas sehingga mampu meningkatkan aktvitas dan motivasi belajar siswa mengikuti proses pembelajaran. Motivasi memegang peranan yang penting dalam proses belajar. Apabila guru dan orang tua dapat memberikan motivasi yang baik pada siswa atau anaknya, maka dalam diri siswa atau anak akan timbul dorongan dan hasrat untuk belajar lebih baik. Memberikan motivasi yang baik dan sesuai, maka anak dapat menyadari akan manfaat belajar 
dan tujuan yang hendak dicapai dengan belajar tersebut. Motivasi belajar juga mampu meningkatkan semangat belajar, terutama bagi para siswa yang malas belajar dan dapat membentuk kebiasaan siswa senang belajar, sehingga prestasi belajarnya pun dapat meningkat. Hal tersebut sesuai dengan pendapat Susilana dan Riyana (2009: 88-89) menyatakan penggunaan media flip chart dalam pembelajaran akan mampu mengoptimalkan aktivitas dan motivasi belajar siswa dan mampu menyajikan pesan pembelajaran secara singkat dan praktis.

Selama proses pembelajaran, siswa bersama dengan kelompoknya memprediksi isi bacaan dan membuat prediksi dalam batas waktu tertentu dan dilanjutkan dengan membacakan hasil prediksi masing-masing, sehingga siswa dalam membuat prediksi penuh tanggung jawab. Rasa tanggung jawab ini perlu dimiliki oleh siswa dalam pembelajaran untuk menemukan jawaban yang paling tepat diantara jawaban yang ada, diperlukan tanggung jawab untuk membenarkan atau menyalahkan jawaban tersebut dengan sumber yang relevan. Tanpa rasa tanggung jawab, kegiatan diskusi tidak akan berjalan lancar untuk menemukan jawaban yang paling tepat karena siswa membenarkan atau menyalahkan pendapat teman tanpa didukung oleh sumber yang relevan. Dengan demikian, rasa tanggung jawab yang dimiliki siswa akan membuat masalah-masalah yang dapat terselesaikan sesuai dengan tuntutan. Pernyataan tersebut sejalan dengan penelitian yang dilakukan oleh Radiarta Wiguna (2014) yang menyatakan bahwa proses pembelajaran dengan penerapan strategi pembelajaran DRTA juga dapat menimbulkan suasana aktif, dinamis, kompetitif dan menumbuh kembangkan rasa tanggung jawab. Dengan suasana dan kondisi seperti itu, tentunya dapat menciptakan proses pembelajaran yang optimal.

Dengan demikian, terbukti bahwa strategi pembelajaran DRTA berbantuan media flip chart menjadikan keterampilan membaca pemahaman siswa lebih baik. Artinya, strategi pembelajaran DRTA berbantuan media flip chart berpengaruh terhadap keterampilan membaca pemahaman siswa kelas V SD di Gugus IV Kecamatan Tejakula Tahun Pelajaran 2017/2018.

\section{Simpulan dan Saran}

Berdasarkan hasil analisis menggunakan uji-t menunjukkan bahwa $t_{\text {hitung }}=16,559$ dan $t_{\text {tabel }}=2,042$. Hal ini berarti nilai $t_{\text {hitung }}>t_{\text {tabel }}$ sehingga terdapat perbedaan yang signifikan strategi pembelajaran Directeed Reading Thinking Activity (DRTA) berbantuan media flip chartterhadap keterampilan membaca pemahaman pada muatan pelajaran bahasa Indonesia. Kualifikasi hasil konversi ke dalam PAP skala lima, rata-rata keterampilan membaca pemahaman bahasa Indonesia siswa yang belajar menggunakan strategi pembelajaran Directeed Reading Thinking Activity (DRTA) berbantuan media flip chart berada pada kategori sangat tinggi. Sedangkan rata-rata keterampilan membaca pemahaman bahasa Indonesia siswa yang belajar tidak menggunakan strategi pembelajaran Directeed Reading Thinking Activity (DRTA) berbantuan media flip chart berada pada kategori sedang. Dengan demikian, dapat berarti bahwa pembelajaran menggunakan strategi pembelajaran Directeed Reading Thinking Activity (DRTA) berbantuan media flip chart berpengaruh signifikan terhadap keterampilan membaca pemahaman bahasa Indonesia kelas V di Gugus IV Kecamatan Tejakula Tahun Pelajaran 2017/2018.

Berdasarkan hasil penelitian yang diperoleh maka dapat disampaikan beberapa saran yaitu sebagai berikut. Siswa hendaknya selalu terlibat secara aktif dalam pembelajaran agar nantinya dapat meningkatkan keterampilan membaca pemahaman dan mendapatkan pengetahuan baru melalui pengalaman yang ditemukannya sendiri. Guru hendaknya lebih berinovasi dalam memilih strategi pembelajaran agar nantinya strategi pembelajaran yang dipilih mampu mengatasi kebutuhan belajar dan karakteristik siswa dan dapat menjadikan strategi pembelajaran DRTA salah satu strategi pembelajaran yang harus diterapkan dalam pembelajaran. Peneliti lain yang akan mengadakan penelitian lebih lanjut tentang pembelajaran DRTA berbantuan media flip chart dalam bidang pelajaran bahasa Indonesia maupun pelajaran lainnya yang sesuai agar memperhatikan kendala-kendala yang dialami dalam penelitian ini sebagai bahan pertimbangan untuk perbaikan dan penyempurnaan penelitian yang akan dilaksanakan.

\section{Daftar Rujukan}

Agung, A.A. Gede. 2014. Metodologi Penelitian Pendidikan. Singaraja: Aditya Media Publishing.

Anggreni ,Putri (2013). Pengaruh Strategi Directed Reading Thinking Activity (Drta) Terhadap Sikap Sosial Dan Kemampuan Membaca Pemahaman Bahasa Inggris Siswa Kelas Viii Smp Dharma Wiweka Denpasar . e-Journal Program Pascasarjana Universitas Pendidikan Ganesha Program Studi Pendidikan Dasar (Volume 3 Tahun 2013)

Dibia, dkk. 2007. Pendidikan Bahasa Indonesia 1. Singaraja: Universitas Pendidikan Ganesha. 
Eddy, dkk. (2014). "Pengaruh Srtategi DRTA Terhadap Keterampilan Menyimak Pada Mata Pelajaran Bahasa Indonesia". e-journal. Mimbar PGSD Undiksha, Vol. 2 No.1 (hal. 5-9).

Fikri ,Hanif (2013). Penerapan Strategi Direct Reading Thinking Activity (Drta) Untuk Meningkatkan Keterampilan Membaca Pemahaman Siswa Kelas V . Jurnal JPGSD Volume 01 Nomor 02 Tahun 2013, 0-216

Fatih ,Mohamad (2019). Peningkatan Membaca Pemahaman melalui Strategi Direct Reading Thingking Activities (DRTA) Siswa Kelas VA SDN Bendogerit 1 Kota Blitar . JURNAL PENDIDIKAN: Riset dan Konseptual Vol. 3 No. 1, January 2019

Hairudin, dkk. 2007. Pendidikan Bahasa Indonesia. Jakarta: Direktorat Jendral Pendidikan Tinggi Departemen Pendidikan Nasional.

Hamsi, Nurul. 2016. "Upaya Meningkatkan hasil belajar IPS dengan metode Ceramah Kelas V”. e-journal. Jurnal Riset dan Konseptual. Vol. 1 No. 1 (hal 1).

Lutfiana ,Eka (2017). Pengaruh Strategi Directed Reading Thinking Activity Terhadap Kemampuan Membaca Intensif Dalam Menemukan Kalimat Utama Di Sdn Mranggen 2 . Jurnal Universitas PGRI Semarang

Rahim, Farida. 2008. Pengajaran Membaca di Sekolah Dasar. Jakarta: PT Bumi Aksara.

Subhanato ,Aprian (2018). Perbandingan Strategi Direct Reading Thinking Activity Dan Strategi KnowWant To Learning Terhadap Keterampilan Membaca Siswa Kelas Iv Sdn 70 Banda Aceh . Jurnal STKIP Bina Bangsa Getsempena

Sugiyono. 2012. Metode Penelitian Kuantitatif, Kualitatif dan R\&D. Bandung: Alfabeta.

Susilana, R \& Riyana, C. 2009. Media Pembelajaran: Hakikat, Pengembangan, Pemanfaatan,dan Penelitian. Bandung: CV Wacana Prima.

Tarigan, Henry Guntur. 1986. Membaca Sebagai Suatu Keterampilan Berbahasa. Bandung: Angkasa.

Undang-undang Republik Indonesia No. 20 Tahun 2003 tentang Sistem Pendidikan Nasional. 2003. Jakarta: Negara Republik Indonesia.

Wiguna, I Wayan Radiarta, dkk. 2014. "Pengaruh Strategi DRTA (Directed Reading Thinking Activity) Terhadap Hasil Belajar Membaca Intensif Siswa Kelas IV Semester 1 SDN Gugus Belantih Kecamatan Kintamani Tahun Pelajaran 2013/2014". e-journal. Jurnal Mimbar PGSD Undiksha, Vol. 2 No. 1 (hal. 4-9). 